Institute of $\mathbf{F}_{\text {ood and }} \mathbf{A}$ gricultural $\mathbf{S}_{\text {ciences }}$

\title{
Forage Moisture Testing ${ }^{1}$
}

\section{G. Chambliss (editor) ${ }^{2}$}

There are several methods and pieces of equipment available to estimate forage moisture. The electronic methods are quick but give more variable results than a microwave or forced-air heating unit such as the Koster Tester.

\section{Electronic Testers}

The most common problems with the electronic probes are related to:

- the need for several probings per bale in order to get an average reading.

- unreliable results because of the varying density of the bale, small sample area, varying texture of the forage, and differences among species.

- erroneous readings when power gets low on battery-operated testers.

- undependable results when estimating moisture in windrow.
To improve reliability, make four to six readings per bale and insert probes into the uncut side of the bale at a $45^{\circ}$ angle to horizontal.

\section{Microwave}

Procedure:

1. Obtain representative sample (whole plants) from swath, silo, or sward.

2. Cut into 1-inch pieces, keeping leaves and stems uniformly mixed.

3. Weigh a plate plus 100 grams of plant sample. It is best to spread sample as uniformly thin as possible. Put a paper towel between the sample and plate to minimize "sweat" from forming on the plate.

4. Put a 10- to 16-ounce covered glass of water in the corner of oven to capture unabsorbed microwaves as the plant tissue dries.

\section{Set oven to HIGH for 5 minutes.}

1. This document is SS-AGR-178, one of a series of the Agronomy Department, Florida Cooperative Extension Service, Institute of Food and Agricultural Sciences, University of Florida. First published 1999. Revised August 2002. The information in this document was adapted from Production and Utilization of Pasture and Forages in North Carolina, Technical Bulletin 305, North Carolina Agricultural Research Service, North Carolina State University and is published with their permission. This publication is also part of the Florida Forage Handbook, an electronic publication of the Agronomy Department. For more information you may contact the editor of the Florida Forage Handbook, C. G. Chambliss (cgc@ mail.ifas.ufl.edu). Please visit the Edis website at http://edis.ifas.ufl.edu.

2. C. G. Chambliss (editor), associate professor, Agronomy Department; Florida Cooperative Extension Service, Institute of Food and Agricultural Sciences, University of Florida, Gainesville, 32611. The use of trade names in this publication is solely for the purpose of providing specific information. It is not a guarantee or warranty of the products named, and does not signify that they are approved to the exclusion of others of suitable composition.

The Institute of Food and Agricultural Sciences is an equal opportunity/affirmative action employer authorized to provide research, educational information and other services only to individuals and institutions that function without regard to race, color, sex, age, handicap, or national origin. For information on obtaining other extension publications, contact your county Cooperative Extension Service office. Florida Cooperative Extension Service/Institute of Food and Agricultural Sciences/University of Florida/Christine Taylor Waddill, Dean. 
6. After 5 minutes, weigh sample and plate and record weight of sample.

7. Change the water and put sample into oven for 2 more minutes. Weigh and record sample weight.

8. Repeat steps 6 and 7 until sample weight does not change more than 1 gram (this means sample is dry).

9. Percent moisture $=100$ grams - dry weight grams.

10. Percent dry matter $=$ the last dry weight of sample (assuming 100 grams, starting wet).

11. With experience you can adjust the time periods and decide whether or not it is necessary to use the glass of water. Usually, the above method gives moisture content that is about $2 \%$ more than true sample moisture content.

12. For hay, the procedure takes 10 to 20 minutes, depending on initial moisture content of sample.

13. Silage samples take 15 to 25 minutes because of coarser particle sizes and grain content, which dries slower.

14. Practice this procedure several times before the day you really need it, because it takes some experience to fine-tune the procedure.

\section{The Grab Test (Squeeze Test)}

This test may be used to show the moisture condition of crops standing in the field, lying in the swath or windrow, or chopped in the wagon. Pick up a handful of finely chopped crop and squeeze tightly (with all your strength) for 90 seconds. Release your grip and note the condition of the ball of crop in your hand. The condition of this ball and the dampness of your hand provide an estimate of the moisture content. (See figures 1a-1d.)

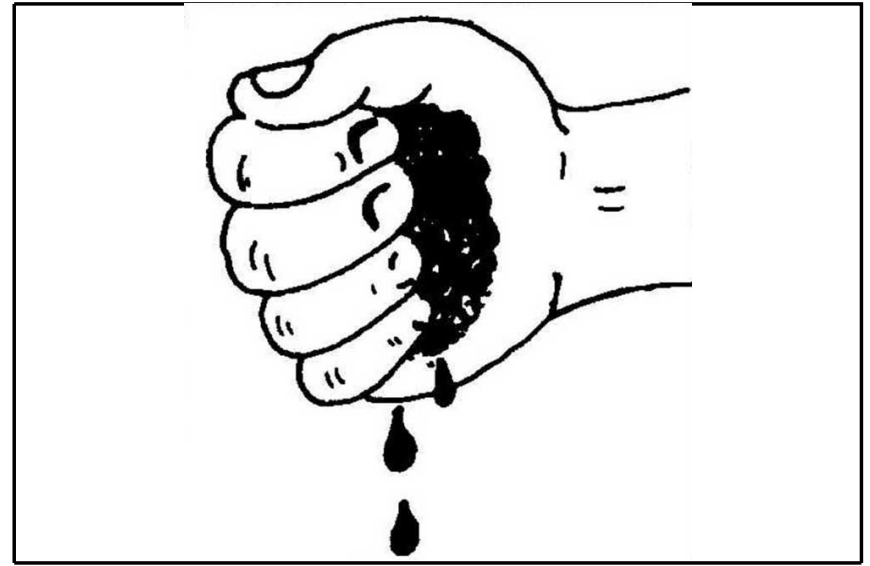

Figure 1a.

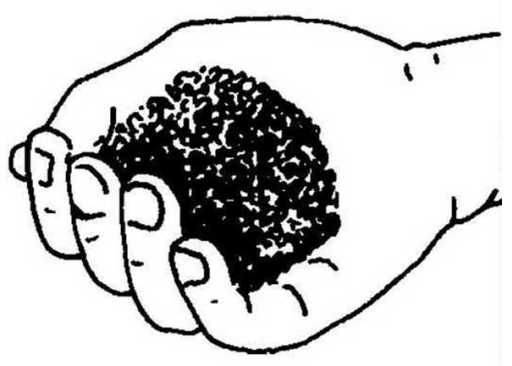

Figure 1b.

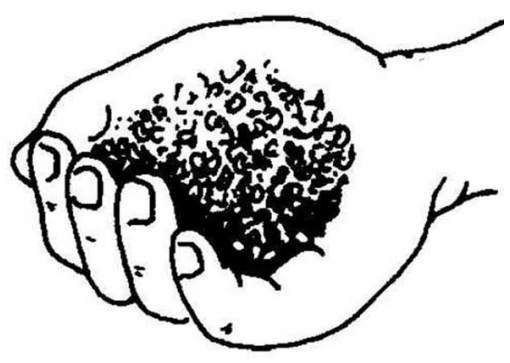

Figure 1c. 


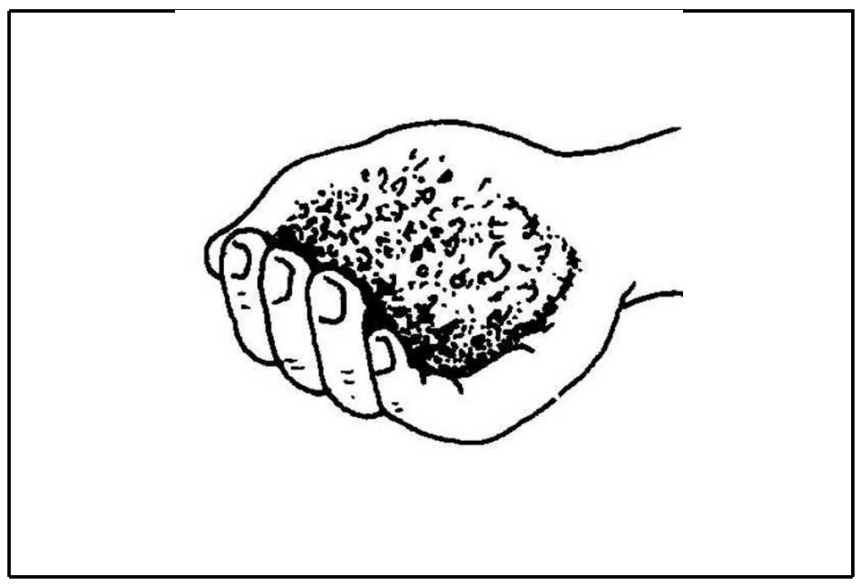

Figure 1d.

Figure 1. If the ball expands slowly and no dampness appears on the hand, the crop contains 60 to $70 \%$ moisture. 